\section{Effects of Several Factors on Saltbush Establishment in California ${ }^{1}$}

\section{EAMOR C. NORD, PATRICK F. HARTLESS, 2 AND W. DENNIS NETTLETON}

Plant Ecologist and Forestry Research Technician, Pacific Southwest Forest and Range Experiment Station, 3 Riverside, California; and Research Soil Scientist, Soil Survey Laboratory, Soil Conservation Service, U.S. Department of Agriculture, Riverside, California.

\section{Highlight}

Certain saltbush taxa can be established by direct seeding and may reduce fire hazards on fuel-breaks in California chaparral areas. Fourwing, allscale, and Gardner saltbushes werc seeded at depths of $1 / 2$ and 1 inch on four spring dates 2 to 4 weeks apart on noncalcareous soils at two test sites. A planting depth of $1 / 2$ inch gave better results than 1 inch, and late spring when mean soil temperatures range between 60 and $65 \mathrm{~F}$ is apparently the best time for seeding if moisture is adequate. Fourwing saltbush produced the best stands and largest plants. The saltbush species and strains from sources closer to the planting site, or similar to it, or have the widest distributional range and tolerance to soil salts are most likely to be established by direct seeding and grow satisfactorily on neutral to slightly acid soil.

The research program aimed at developing fuel-breaks in southern California has included a search for woody plants to replace the highly flammable chaparral. Among the more promising plants are saltbushes (Atriplex). These shrubs furnish browse for livestock and big game, cover and food for upland game birds, and are useful to stabilize soils and improve the landscape. A few saltbush species have high fuel moisture levels and some are low growing, features which would make them more acceptable to fire fighters than the native brush.

Saltbush species occupy vast areas from the western Great Plains and southern Saskatchewan, Canada, into California and Mexico. They withstand drought and many tolerate severe cold. They are generally found in saline and alkaline soils

${ }^{1}$ Received May 2, 1970; accepted for publication September 21, 1970.

${ }^{2}$ Present address is Forestry Research Technician, Intermountain Forest and Range Experiment Station, Forest Service, U.S. Department of Agriculture, Ogden, Utah, stationed at Missoula, Montana.

${ }^{3}$ Forest Service, U.S. Department of Agriculture with headquarters at Berkeley, Cialifornia.
(pH 7.0 to 8.6 ), but not all species are restricted to these conditions (Vosler, 1962; McLean, 1953; Gates et al., 1956). Growth habits range from erect to squat. When the seed source is adequate, they invade and occupy extremely eroded or disturbed areas; thus they might be expected to survive the harsh conditions in southern California ing to be economical over extensive areas, methods must be developed for establishing stands by direct seeding.

Fourwing saltbush $(A \text {. canescens })^{4}$ was considered a good possibility to improve selected western rangelands as early as 1870 . But results of direct seedings have been erratic. Failures have been attributed to low seed germination, planting at the wrong depth or time of year, poor growing conditions, inadequate seedbed preparation, and removal of seeds or clipping of young plants by rabbits and rodents (Bridges, 1941 and 1942; Reynolds et al., 1949; Plummer et al., 1968; Springfield, 1963).

${ }^{4}$ Nomenclature used in this report is that followed by Holmgren and Reveal (1966). fuel-breaks. However, for plant-
Little information is available on how to plant the seed of native saltbushes, other than the fourwing saltbush, to obtain satisfactory stands. Springfield and Bell (1967) recommended seeding depths of $1 / 2$ to 1 inch for fourwing saltbush in New Mexico. However, Cassady (1937) and Bridges (1941) rcportcd seedling emergence by this species declined when seed was sown more than $1 / 2$ inch deep.

General agreement is lacking as to the best time for seeding any saltbushes. Springfield and Housley (1952) found that April and June seedings of fourwing saltbush made at 7,000 ft or higher elevations in New Mexico were more successful than later plantings. In Utah, Plummer et al. (1968) reported better stands generally followed seedings made in fall and winter, but in some instances spring plantings were also successful.

A study of temperature effects by Springfield (1966) showed better germination of fourwing saltbush at both 63 and $49 \mathrm{~F}$ than at $85 \mathrm{~F}$. Moisture stress had less effect on germination at $63 \mathrm{~F}$ than at other temperatures. Hervey and Boyd (1953) reported $95 \%$ of fourwing saltbush seedlings emerged in 21 days or less when planted at $1 / 2$-inch depth where temperatures ranged between 63 to $72 \mathrm{~F}$. The most favorable temperatures for allscale or desert saltbush ( $A$. polycarpa) seed germination were between 60 and $80 \mathrm{~F}$ (Chatterton, 1970; Cornelius and Hylton, 1968).

To determine if feasible methods can be developed to establish saltbushes successfully by direct seeding, we designed a study to test the effects of depth and time of seeding on seedling emergence, growth, and survival on noncalcareous soil in southern California. The species used were chosen to represent different growth forms and different source locations; they included two ecotypes of fourwing and allscale saltbushes and one each of Gardner ( $A$. gardneri) and "falcata" ( $A$. falcata) saltbushes. 


\section{Planting Sites}

The study was carried out on two plots-Nixon and Vista Grande-in the North Mountain Experimental Area, near Beaumont, Riverside County, California. Earlier planting trials mostly by potted transplants showed a number of saltbush species could be established and grown successfully at these locations, which are in the San Jacinto Mountain Range at $3,600 \mathrm{ft}$ (Nixon) and 5,000 ft (Vista Grande).

The mean annual precipitation at the Nixon plot is about 23 inches and at the Vista Grande plot, 32 inches. Most rainfall comes between October and April; summers are hot and dry. Between September 1965 and January 1966, total estimated precipitation was 15 inches at the Nixon plot and 19 inches at Vista Grande. From February to April, when seedlings were developing, an additional 3 inches of rain fell on each site but practically none thereafter.

Vegetation near the plots is mixed chaparral. The principal plants include scrub oak (Quercus dumosa), manzanita (Arctostaphylos spp.), chamise (Adenostoma fasciculatum), ceanothus (Ceanothus spp.), and mountain mahogany (Cercocarpus betuloides), with abundant annual grasses and forbs.

Both planting areas lie on moderately broad, gently sloping mountain ridgeline saddles with southerly exposure. The soils at the two plots are formed in alluvial fan sediments from granodiorite. They are very deep, moderately coarse-tocoarse textured and rapidly permeable. The soil at the Nixon plot is in a coarse-loamy, mixed, mesic family of Typic Haploxerolls, that at the Vista Grande plot in a sandy, mixed, nonacid, mesic family of Typic Xerofluvents (U.S. Soil Conservation Service, 1967).

Though the top 2 inches of soil at the two plots contain similar amounts of clay (4 to $5 \%$ ) the Nixon plot has $9 \%$ clay between 10 and 40 inches whereas the Vista Grande plot has only $4 \%$. The organic carbon content of the soil is higher near the surface but lower at depths below 2 inches at the Nixon plot than at the Vista Grande plot. Ihese differences in clay and organic carbon counterbalance so that the cation exchange capacity of the two soils is nearly the same. Base saturation of the soil at the Nixon plot is 83 to $100 \%$, that at Vista Grandc only 43 to $59 \%$. The soil on the Nixon plot is medium acid to neutral in reaction $(\mathrm{pH} 5.8$ to 7.1), that at Vista Grande is slightly acid (pH 6.1 to 6.4). The top 2 inches soil contained $9.1 \mathrm{me} /$ $100 \mathrm{~g} \mathrm{Ca}$ and $1.9 \mathrm{me} / 100 \mathrm{~g} \mathrm{Mg}$ at Nixon, and $4.0 \mathrm{me} / 100 \mathrm{~g} \mathrm{Ca}$ and

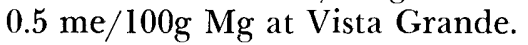

Water content of the surface 2 inches soil at the Nixon plot ranged between 10 to $14 \%$ from March 10 , when the first records were taken, until April 21; thereafter it was less than $7 \%$. At the Vista Grande plot, water content was from 7 to 9\% throughout March and then declined to $6 \%$ or less except on April 21 when water content was just over $8 \%$. Water retention of thesc soils showed the wilting point ( 15 bars) was 5.2 and $3.4 \%$, respectively, at Nixon and Vista Grande plots, and field capacity ( $1 / 3$ bar) was $11.4 \%$ for soils at both plots. Water repellency analysis made by $L$. F. DeBano, U.S. Forest Service, Glendora, California, showed the liquid solid contact angles of the surface soils were $72^{\circ} 58^{\prime}$ at Nixon and $67^{\circ} 43^{\prime}$ at Vista Grande. The liquidsolid contact angle is an index to the relative wettability of soils which, in southern California, are frequently hydrophobic and may have an adverse effect on seed germination and plant establishment. A large contact angle decreases the rate of water entering the surface of the soil, while a smaller contact angle increases the rate of water entry (Letey et al., 1962; Osborn et al., 1967).

Mean soil temperatures measured at 1-inch depth for 21 day periods were 59,67 , and $65 \mathrm{~F}$ at the Nixon plot following saltbush seedings made on March 3 and 22 and on April 6, respectively. At the Vista
Grande plot, soil temperatures were $55 \mathrm{~F}$ following the March 4 seeding and $62 \mathrm{~F}$ following the March 24 and April 7 seedings.

\section{Methods}

The plots were disc-plowed during early winter, and the soil was allowed to settle until planting time. Before seeding, the surface soil was scalped and smoothed to make a uniform seedbed and reduce competition from plants which had germinated during the interval between tilling and planting.

Seedings were made at $1 / 2$ - and l-inch depths on February 4-5, March 3-4, March 22-24, and April $6-7,1966$. Five replications with 5 seed spots at $1-\mathrm{ft}$ intervals in rows $3 \mathrm{ft}$ apart were seeded for each time, depth, and kind of plant tested at each plot. Random selection determined the row segment representing timc of sccding within a replication, and the position of the 5 seed spots within each row which represented depth and kind of seed. Fourwing saltbush seed used had been scarified to remove winged bracts and graded to pass through $6 / 64 \times 1 / 2$ inch slotted sieve openings (Nord and Whitacre, 1957); no treatment was applied to seed of the other species. Several seeds were planted at each spot in wedge-shaped openings. An equal volume of seed was measured for each species or strain, but the number of seed varied between these groups. The number planted were based upon the total amount of seed available for some species or strains and not primarily on their potential germination (Table 1). Seed was covered with soil and the surface tamped lightly to enhance moisture conductivity of unsaturated soil. Spots were covered with wire mesh domes to protect seed and seedlings from animals. Competing plants were removed by rototilling between the rows twice during the summer.

Tallies of spots on which one or more seedlings had emerged were made at 1- to 2-week intervals between March and June. At the 
Table 1. Source, germination potential (\%), and number of saltbush seeds used in seeding tests, North Mountain Experimental Area, California.

\begin{tabular}{|c|c|c|c|c|}
\hline Species $^{1}$ & $\begin{array}{l}\text { Source location } \\
\text { and elevation }\end{array}$ & $\begin{array}{l}\text { Year seed } \\
\text { collected }\end{array}$ & $\begin{array}{c}\text { Potential } \\
\text { germination }\end{array}$ & $\begin{array}{l}\text { Seeds planted } \\
\text { each spot }\end{array}$ \\
\hline Fourwing saltbush (Atriplex canescens) & $\begin{array}{l}\text { Moreno Valley, Riverside } \\
\text { Co., Calif. } 1,000 \mathrm{ft}\end{array}$ & 1965 & 35 & 20 \\
\hline Fourwing saltbush (Atriplex canescens) & $\begin{array}{l}\text { Cactus Flat, San Bcrnardino } \\
\text { Co., Calif. } 5,800 \mathrm{ft}\end{array}$ & 1965 & $\left({ }^{2}\right)$ & 18 \\
\hline Allscalc or descrt saltbush $(A$. polycarpa) & $\begin{array}{l}\text { Casa Grande, Pinal Co., } \\
\text { Arizona } 1,400 \mathrm{ft}\end{array}$ & 1965 & 60 & 12 \\
\hline Allscalc or descrt saltbush $(A$. polycarpa) & $\begin{array}{l}\text { Little Lake, Inyo Co., } \\
\text { Calif. } 3,000 \mathrm{ft}\end{array}$ & 1965 & 60 & 31 \\
\hline "Falcata" saltbush ( $A$. falcata) & $\begin{array}{l}\text { Battlc Mountain, Lauder } \\
\text { Co., Calif. } 4,500 \mathrm{ft}\end{array}$ & 1965 & 6 & 20 \\
\hline Gardner saltbush $(A$. gardneri $)$ & $\begin{array}{l}\text { Ephraim, Sanpcte Co., } \\
\text { Utah } 5,500 \mathrm{ft}\end{array}$ & 1963 & 10 & 36 \\
\hline
\end{tabular}

${ }^{1}$ Nomenclature used is that followed by Holmgren and Reveal (1966).

${ }^{9}$ Germination data not available.

same time, five samples of soil at 0 to 2-inch depths from each plot were collected and soil moisture was determined.

Beginning in early March, automatic recording instruments measured soil temperatures at 1 -inch depth at both sites. Precipitation after early March was measured with standard rain gauges.

Maximum height and average foliar crown spread were measured, and flowering or fruiting by the plants was determined at the conclusion of the first season's growth. The root systems of representative plants of three species were excavated at the Nixon plot to determine the kind and extent of rooting.

Analysis of variance using arc sin transformations and Duncan's Multiple Range Test of data tested effects of time and depth of planting on percentage of seedling emergence and subsequent plant development. Chi square tests were used to evaluate effects of thesc factors on incidence of flowering.

\section{Results}

\section{Seedling Emergence}

Seedling emergence varied considerably according to the plot, spe- cies, strain, depth, and time of seeding. Higher emergence developed at Nixon than Vista Grande for all species and conditions tested. More fourwing saltbush plantings emerged than plantings of any other species, with 90 and $65 \%$ maximum, respectively, from seed spots at Nixon and Vista Grande. All plantings of "falcata" saltbush failed at both plots. Plantings of Gardner saltbush and Arizona strain allscale saltbushes at the Vista Grande plot also failed as did-to a certain extent-those at the Nixon plot. Therefore, these results were not used except as appropriate for further analysis or evaluation of the data.

Seedling emergence of all saltbushes tested was significantly affected by both time and depth of seeding. Emergence from $1 / 2$-inch depth was generally greater than from 1-inch depth at both plots, and for most planting dates (Table 2). Seeding depth effects were more pronounced on plantings made in February and March than on those made in April. More seedlings emerged from $1 / 2$-inch depth for the first three plantings than at the 1inch depth, but essentially the same number developed from both depths for the April planting. The average percentages of seed spots with one or more seedlings by depth classes, irrespective of planting dates, were as follows:

\begin{tabular}{|c|c|c|c|}
\hline \multicolumn{2}{|c|}{ Nixon } & \multicolumn{2}{|c|}{ Vista Grande } \\
\hline $1 / 2$ inch & 1 inch & $1 / 2$ inch & 1 inch \\
\hline & \multicolumn{3}{|c|}{ Fourwing (2 strains) } \\
\hline 73 & 63 & 30 & 15 \\
\hline \multicolumn{3}{|c|}{ Allscale (1 strain) } & 9 \\
\hline \multicolumn{4}{|c|}{ Gardner (1 strain) } \\
\hline
\end{tabular}

${ }^{1}$ Seedings failed at the Vista Grande site.

Time of seeding was an important factor in the number of saltbush seedlings that emerged. More seedlings were produced from plantings in late March at the Nixon plot or in early April at the Vista Grande plot than from any other plantings (Table 2). Analysis of the pooled data showed these differences between dates were statistically significant (5\% level), however, this significance did not necessarily apply for each species or all conditions tested. For example, there was some overlap between dates and in a very few instances between planting depths as to which seeding dates produced the higher emergence. 
Table 2. Seed spots (\%) stocked with 1 or more seedlings in saltbush plantings at two sites, by species, depth, and time of seeding, North Mountain Experimental Area, California.

Site, species, depth $\quad$ Feb. 4-5 $\quad$ March 3-4 March 22-24 April 6-7

Nixon

Fourwing saltbush ${ }^{1}$

$\begin{array}{lllll}1 / 2 \text { inch } & 52 \mathrm{bc}^{3} & 83 \mathrm{de} & 90 \mathrm{e} & 67 \mathrm{~cd} \\ 1 \text { inch } & 19 \mathrm{a} & 50 \mathrm{bc} & 30 \mathrm{ab} & 73 \mathrm{cde}\end{array}$

Allscale saltbush1

$1 / 2$ inch

1 inch

22 cde

Gardner saltbush ${ }^{2}$

$1 / 2$ inch

$73 \mathrm{c}$

1 inch

$19 \mathrm{ab}$

Vista Grande

Fourwing saltbush 1

$1 / 2$ inch

1 inch

$18 \mathrm{ab}$
$4 \mathrm{a}$

Allscale saltbush ${ }^{2}$

$1 / 2$ inch

1 inch

$\begin{array}{cr}10 a b c & 27 b c \\ 1 a & 3 a b\end{array}$

1 Two strains.

${ }^{2}$ One strain.

${ }^{3}$ Values followed by the same letter do not differ significantly at the $5 \%$ probability level within each species and plot according to Duncan's Multiple Range Test.

\section{Seedling Survival and Stand Development}

Most saltbush seedlings present in late June on the Nixon plot survived and grew satisfactorily, but survival to late June varied by species, time, and depth of seeding. At Vista Grande only about a dozen fourwing saltbush plants lived through the first growing season; all other saltbush seedlings died, generally within 3 weeks after emergence. The near absence of plants on this plot precluded any further observations at the site.

Seedling survival from emergence until late June averaged $88 \%$ by fourwing, $60 \%$ by allscale, and $68 \%$ by Gardner saltbushes at the Nixon plot (Table 3). With a few exceptions, a larger proportion of seedlings survived from the $1 / 2$-inch planting depth than from the Iinch depth. No allscale saltbush seedlings survived from plantings at 1 inch on the two earliest dates; $60 \%$ or higher of those planted at
Time of secding

$8 \mathrm{abc}$

$40 \mathrm{e}$

$12 \mathrm{bc}$

$35 \mathrm{de}$

$35 \mathrm{ab}$

$73 \mathrm{c}$

$44 \mathrm{bc}$

$8 a$

$8 \mathrm{a}$

44bc

$8 a$

$36 \mathrm{bc}$

$25 \mathrm{bc}$

$43 \mathrm{c}$

$6 \mathrm{a}$

$5 \mathrm{a}$

$46 \mathrm{c}$

$3 a b$

$48 \mathrm{c}$

$0 \mathrm{a} \quad 31 \mathrm{bc}$
$1 / 2$ inch on these dates survived. Survival from subsequent seedings of this species was nearly the same from both planting depths. Except for the earliest planting date, when Gardner saltbush seedling survival was low from both planting depths, survival rates were at least $50 \%$ higher from $1 / 2$ inch than from $I$ inch.

Date of seeding was an important factor in rate of stand development-the interval in days between planting and 90\% total seedling emergence-by fourwing and allscale saltbush at the Nixon plot. Depth of seeding and strain appeared to have only a limited effect in this respect. Fourwing saltbush seeded on February 5 and March 3 took 4 and 2 weeks longer to reach 90\% emergence than did March 24 or April 7 seedings. The average intcrval for stands to develop ranged from 50 days for plantings made on February 5 to 23 days for both the March 24 and April 7 plantings. The period was intermediate for the March 3 planting.

There were differences in rate of stand development between fourwing saltbush strains. Seedling stands of the Moreno strain developed in 1 to 3 wecks less timc than those of the Cactus Flat strain for plantings made on February 5 and March 3; subsequent seedings showed practically no differences betwecn rate of stand development for these two strains.

Stand development by allscale saltbush was 5 to 14 days ahead of fourwing saltbush. The average intervals required by this species to devclop stands werc 41 and 15 days, respectively, for February 5 and April 6 plantings. The intervalsnearly the same for both March plantings-were intermediate between those for the other seedings. We were unable to determine any effects that depth or strains may have on rate of stand development by allscale or Gardner saltbush because of the scarcity of seedlings from some of these plantings.

Table 3. Saltbush seedling survival (\%) in late June at Nixon plot, North Mountain Experimental Area, California, planted at two depths.

\begin{tabular}{|c|c|c|c|c|c|c|}
\hline \multirow{2}{*}{$\begin{array}{l}\text { Planting } \\
\text { dates }\end{array}$} & \multicolumn{2}{|c|}{$\begin{array}{l}\text { Fourwing saltbush } \\
\text { (2 strains) }\end{array}$} & \multicolumn{2}{|c|}{$\begin{array}{l}\text { Allscale saltbush } \\
\text { (2 strains) }\end{array}$} & \multicolumn{2}{|c|}{$\begin{array}{c}\text { Gardner saltbush } \\
\text { (1 strain) }\end{array}$} \\
\hline & $1 / 2$ inch & 1 inch & $1 / 2$ inch & 1 inch & $1 / 2$ inch & 1 inch \\
\hline February 5 & 100 & 92 & 72 & 0 & 53 & 40 \\
\hline March 3 & 97 & 76 & 60 & 0 & 100 & 66 \\
\hline March 24 & 93 & 69 & 84 & 86 & 88 & 62 \\
\hline April 6 & 90 & 91 & 90 & 91 & 100 & 33 \\
\hline Average & 95 & 82 & 76 & 44 & 85 & 50 \\
\hline
\end{tabular}


Table 4. Effect of seeding depths and planting dates on first season's growth and flowering by fourwing and allscale saltbushes at Nixon plot, North Mountain Experimental Area, California.

Dates seeded

\section{Species and strain}

Feb. $5 \quad$ March $3 \quad$ March 24

April 6

Volume index size of plants $\left(\mathrm{ft}^{3}\right)$

Fourwing saltbush (average for 2 strains) ${ }^{1}$

1/2-inch depth

1-inch depth
$57.8 \mathrm{a}^{2}$

$32.3 \mathrm{~b}$

$35.3 \mathrm{~b}$

$44.3 \mathrm{~b}$

$34.3 \mathrm{~b}$

$39.7 \mathrm{~b}$

$26.6 \mathrm{~b}$

$31.1 \mathrm{~b}$

Allscale saltbush (1/2-inch depth only)

Casa Grande, Arizona strain

Little Lake, Calif. strain
1.3

21.1
4.9

(3)
2.0

17.6

11.3

Pistillate and staminate flowering (\%)

Fourwing saltbush (average for 2 depths) ${ }^{4}$

Moreno, Calif. strain ${ }^{2}$

Cactus Flat, Calif. strain

Allscale saltbush (1/2-inch depth only)

Casa Grande, Arizona strain²

Little Lake, Calif. strain
$43 \mathrm{a}$

$0 \mathrm{~b}$

$56 \mathrm{a}$
$7 \mathrm{~b}$

$7 \mathrm{~b}$

$49 a$

$3 \mathrm{~b}$

$5 b$

$0 \mathrm{~b}$

\footnotetext{
${ }^{1}$ No significant differences between size of plants according to fourwing saltbush strains tested.

${ }^{2}$ Values followed by the same letter within each category and line do not differ significantly at 5\% level as determined by Duncan's Multiple Range Test for size of plants, and by chi-square analysis for test of flowering.

${ }^{3}$ No data available on size of allscale saltbush plants from seedings on March 3.

${ }^{4}$ No significant differences between the two seeding depths for frequency of flowering by fourwing saltbush.
}

\section{Growth and Reproduction}

There was evidence that time, depth of seeding, and strain affected ultimate plant size and amount of flowering in fourwing saltbush and to a limited extent in allscale saltbush. Early season plantings generally produced the larger plants (Table 4). Fourwing saltbush plants from seedings at $1 / 2$ inch on February 5 averaged 44 inches tall with a volume index of $58 \mathrm{ft}^{3}$, and were significantly larger than plants from other seeding dates or from seedings at 1 inch depth. There were small but not significant differences in plant size between strains of fourwing saltbush. Differences in growth of the two strains of allscale saltbush were pronounced. The Little Lake strain had an average volume index of 14.9-as compared to 2.0 for plants from the Casa Grande strain (Table 4). Plants of both strains which developed from seedings made in February or March were nearly two times larger than plants from the April seeding.

The incidence of flowering, either staminate or pistillate, varied according to the strains. In the Moreno strain of fourwing and the Casa Grande strain of allscale saltbushes, between 25 and $56 \%$ of plants flowered. There was practically no flowering on plants of the other strains of these species, or on any Gardner saltbush. Date of planting affected flowering only for the April seeding of the Moreno strain of fourwing saltbush, which resulted in significantly fewer plants with flowers than earlier seedings. The amount of flowering by the Casa Grande strain of allscale saltbush was essentially the same for all four seeding dates.

\section{Root Systems of Saltbush Plants}

Roots were more extensive in all respects than the areal portions of the three species studied (Fig. 1). A fourwing saltbush plant that was
$31 / 2 \mathrm{ft}$ tall with a 4 -ft diameter foliar crown had roots $61 / 2 \mathrm{ft}$ deep and laterals that extended over a 10 -ftdiameter area in the soil (Tablc 5). Roots of allscale and Gardner saltbushes were less extensive. Plants that were $2 \frac{1}{2}$ and $2 \mathrm{ft}$ tall and nearly the same across the crown had roots that were $4 \frac{1}{2}$ to $31 / 2 \mathrm{ft}$ deep and spread 5 to $7 \mathrm{ft}$ outward. Gardner saltbush produced suckers to form new plants. These shoots, which emerged up to 24 inches outward from the plant, originated from lateral roots that were less than 12 inches below the surface (Nord et al., 1969).

\section{Discussion and Conclusions}

Results of this study demonstrated that certain saltbushes can be established successfully in southern California by direct seeding and may grow satisfactorily on soils that are slightly acid in reaction even though their native habitat is generally on basic soils. Establishment depends on the species and strain, time and depth of seeding, soil moisture and soil temperatures, among other factors. The optimum conditions for seeding these saltbushes in southern California appears to be late in the spring when mean soil temperatures range between 60 and $65 \mathrm{~F}$ if moisture is adequate and seeds are planted at $1 / 2$-inch depth.

Saltbush species and strains from sources closer to the planting site, or similar to it, or have the widest distributional range and tolerance to soil salts are most likely to be established successfully by direct seeding and grow satisfactorily on neutral to slightly acid soils. This was evident with fourwing saltbush that produced the best stands and the largest plants, and its roots extended deeper and wider than those of either allscale or Gardner saltbushes. Flowering by plants during the first season was observed on single strains of both fourwing and allscale saltbush. Flowering by the other strains of these and Gardner saltbushes was rare or did not occur at all during the first season. 


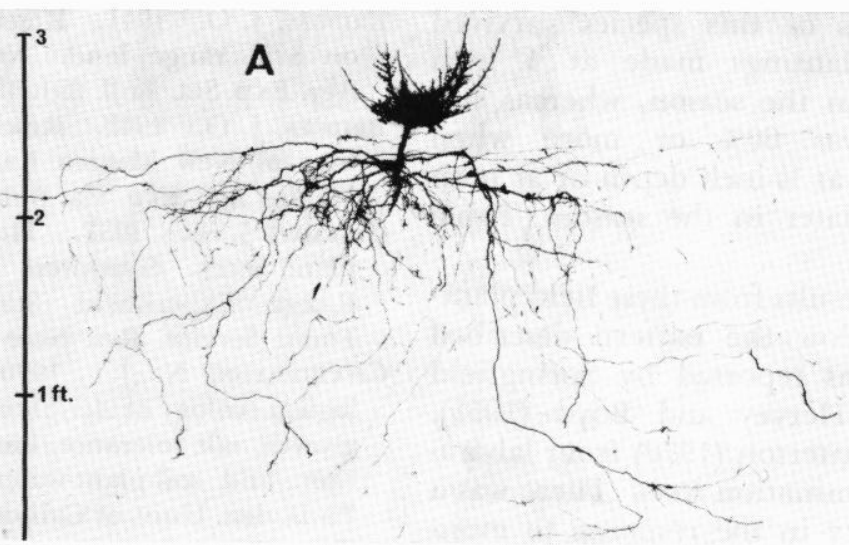

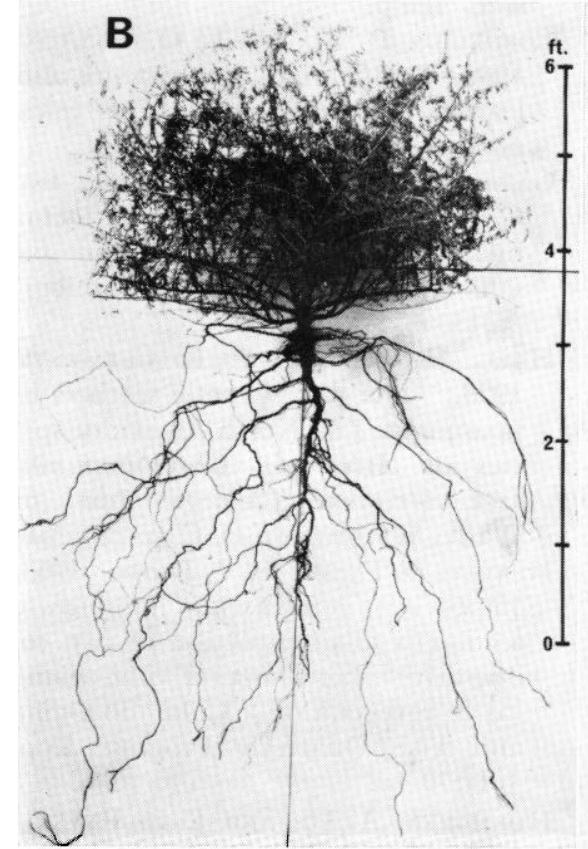

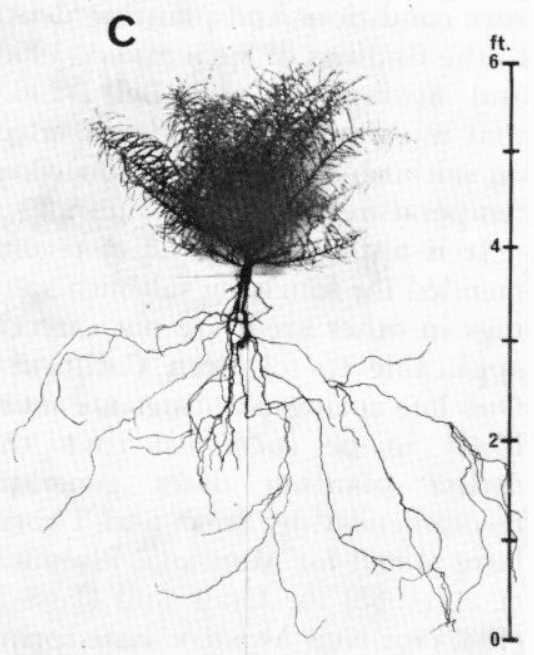

Fig. 1. Root systems of saltbush plants at end of first growing season on the Nixon plot, North Mountain Experimental Area, California: (A) Gardner; (B) fourwing; (C) allscale or desert.

Table 5. Foliar and root system development of representative saltbush plants at the end of the first growing season at Nixon plot, North Mountain Experimental Area, California.

\begin{tabular}{lccccc}
\hline \hline $\begin{array}{c}\text { Species } \\
\text { and } \\
\text { strain }\end{array}$ & $\begin{array}{c}\text { Height } \\
\text { (inch) }\end{array}$ & $\begin{array}{c}\text { Crown } \\
\text { diameters } \\
\text { (inch) }\end{array}$ & $\begin{array}{c}\text { Volume } \\
\text { index } \\
\left(\mathrm{ft}^{3}\right)^{1}\end{array}$ & $\begin{array}{c}\text { Depth- } \\
\text { maximum } \\
\text { (inch) }\end{array}$ & $\begin{array}{c}\text { Lateral } \\
\text { spread } \\
\text { (inch) }\end{array}$ \\
\hline $\begin{array}{c}\text { Fourwing saltbush } \\
\quad \text { Moreno, Calif. }\end{array}$ & 42 & 41 & 40.1 & 75 & 60 \\
$\quad$ Cactus Flat, Calif. & 38 & 42 & 41.2 & $(2)$ & $\left({ }^{2}\right)$ \\
$\begin{array}{c}\text { Allscale saltbush } \\
\quad \text { Casa Grande, Ariz. }\end{array}$ & 17 & 16 & 2.0 & - & - \\
$\quad \begin{array}{l}\text { Little Lake, Calif. } \\
\text { Gardner saltbush }\end{array}$ & 28 & 36 & 14.9 & 55 & 42 \\
$\quad$ Ephraim, Utah & 5 & 6 & 0.1 & 45 & $30^{3}$ \\
\hline
\end{tabular}

${ }^{1}$ Product of height $\times$ foliar crown diameter.

${ }^{2}$ Data not available on root systems of these saltbush strains.

${ }^{3}$ Lateral roots contained suckers which formed new plants.
Differences in performance among the saltbush species and strains tested can be attributed largely to their inherent adaptability to the conditions on the planted sites. Performance of the species and strains tended to be inversely related to the distances between seed source origins and the planted sites. This applied to fourwing, allscale, and Gardner saltbushes which produced good, fair, and poor stands, respectively. Fourwing came from a nearby source, allscale was intermediate, and Gardner came from farthest away. The same trend appeared between the two strains of allscale saltbush. The Little Lake strain produced better stands than the Casa Grande strain, which came from a more distant location. The differences in performance appeared to be directly related to the extent of the native range and tolerance to soil salts of the various species and strains.

As indicated earlier, soils on the test sites are neutral to slightly acid, whereas soils where these saltbushes occur naturally are generally basic. Of the three species, fourwing saltbush has the most extensive distribution and the widest tolerance to soil salts, allscale is intermediate, and Gardner saltbush ranks lowest in both respects (Branson et al., 1967; Hall and Clements, 1923). The Vista Grande plot, with low base saturation and smaller amounts of $\mathrm{Ca}$ and $\mathrm{Mg}$, may not have been as favorable for these species as the Nixon plot, which had a higher base saturation and more $\mathrm{Ca}$ and $\mathrm{Mg}$.

It was evident that differences in soil moisture and soil temperatures were responsible for the differences in seedling emergence for all strains between Vista Grande and Nixon. At the Nixon plot, where satisfactory stands developed from most plantings, both soil moisture and temperatures were higher than at Vista Grande during the spring. For corresponding dates or periods, soil moisture was, for the most part, 50 to $110 \%$ higher and soil tempera- 
tures 3 to $5 \mathrm{~F}$ warmer at Nixon than at Vista Grande plots.

Another factor may have been the larger proportions of organic matter, especially in the 0 - to 3inch level, and \% clay throughout, at Nixon as compared to Vista Grande. To judge by the soils where they generally occur in the southwestern United States, saltbushes probably have high calcium and magnesium requirements for growth. The Nixon plot has more calcium than the Vista Grande plot.

Water repellency of the soil could not be associated with the differences in moisture content of the soils on the two plots. 'I he higher liquid-solid contact angle of the soil at the Nixon plot indicates it may be more repellent than soil at the Vista Grande plot (Letey et al., 1962).

Total rainfall or its distribution did not account for the differences in soil moisture between the two sites. Only 2 inches rainfall was received shortly after the earliest seedings and 1 inch came from three intermittent storms.

The higher temperatures that occur near the surface when heat is moving downward in the spring (Russell, 1950) are probably responsible for better germination and better seedling establishment at $1 / 2$ inch seeding depths. Available soil moisture could not account for these differences. If it did, one would expect more seedlings from deeper planting depth where soil moisture content remains longer in a favorable range.

Lower seedling survival from 1inch depth is attributed to the weakened condition of the seedlings because they exhaust food reserves in the seed during the longer period from initial germination until the plant can manufacture its own supply. Such seedlings are more susceptible to damping-off, soil drying, and other adverse factors than seedlings that are healthy or more advanced in development. Allscale saltbush had the smallest seed and probably the lowest food reserve of the species tested. No seedlings of this species survived from plantings made at 1 inch earlier in the season, whereas survival was $60 \%$ or more when planted at $1 / 2$-inch depth or at both depths later in the season (Table 3).

The results from these field plantings follow the pattern described earlier as reported by Springfield (1966), Hervey and Boyd (1953), and Chatterton (1970) from laboratory germination tests. There was a similarity in the response to moisture conditions and planting depth to the findings of Springfield (1966) and Springfield and Bell (1967) that moisture stress has least effect on saltbush seed germination when temperatures are near optimum.

It is apparent that dates recommended for fourwing saltbush seedings in other areas are not directly applicable to southern California. Our late spring plantings are more likely to be successful than the earlier planting dates generally recommended by Stroh and Thornburg (1969) for Montana, Plummer et al. (1968) for Utah, and Cassady (1937) for New Mexico. Late spring seeding should provide for more rapid germination and seedling emergence, minimize the dangers of frost heaving and damping-off, and allow opportunity to reduce competition by other plants. Although no field seeding tests were made during the fall or early winter, there is good reason to believe such plantings would be damaged by lack of adequate moisture and low temperatures such as were present following the February seedings. It is also likely that saltbush seedlings would be suppressed or crowded out by the profuse stands of annual herbaceous plants that generally develop during the winter.

\section{Literature Cited}

Branson, F. A., R. F. Miller, ANd I. S. MaQueEn. 1967. Geographic distribution and factors affecting the distribution of salt desert shrubs in the United States. J. Range Manage. 20:287-296.
Bridges, J. O. 1941. Reseeding trials on arid range land. New Mexico Agr. Exp. Sta. Bull. 291.48 p.

BrIngF, J. O. $1942 . \quad$ Reseeding practices of New Mexico Ranges. New Mexico Agr. Exp. Sta. Bull. 291. 48 p.

Cassady, J. T. 1937. How deep to plant seeds. Southwest Forest and Range Experiment Station, U.S. Forest Service, Res. Note 14. 2 p.

Chatterton, N. J. 1970. Physiological ecology of Atriplex polycarpa: growth, salt tolerance, ion accumulation, and soil-plant-water relations. Ph.D. diss. Univ. of California, Riverside. $120 \mathrm{p}$.

Cornelius, D. R., and L. O. Hylton. 1968. Influence of temperature and leacheate on germination of Atriplex polycarpa. Agron. J. 61:209-211.

Gates, D. H., L. A. Stoddard, ANd C. W. Cook. 1956. Soil as a factor influencing plant distribution on salt-deserts of Utah. Ecol. Monogr. 26:155-176.

Hall, H. M., and F. E. Clements. 1923. The phylogenetic method in taxonomy. The North American species of Artemesia, Chrysothamnus, and Atriplex. Carnegie Inst. of Wash., Washington D. C. p. 235-346. Hervey, D. F., AND R. J. Boyd. 1953. Improving germination of browse seed. (In job completion report, cooperative experimental big game range revegetation.) Colorado Game and Fish Quarterly Progress Rep. July:79-86.

Holmgren, A. H., and J. L. Reveal. 1966. Checklist of the vascular plants of the Intermountain Region. U.S. Dep. Agr., Forest Serv., Intermountain Forest and Range Exp. Sta. Res. Paper INT-32, $160 \mathrm{p}$.

Letey, J., J. Osborn, and R. E. PeliSHEK. 1962. Measurement of liquidsolid contact angles in soil and sand. Soil Sci. 43: 149-153.

McLean, Alastair. 1953. The autecology of Atriplex nuttallii S. Wats. in southwestern Saskatchewan. M.S. thesis, Utah State Agr. College, Logan, Utah. $69 \mathrm{p}$.

Nord, E. C., ANd J. E. Whitacre. 1957. Germination of fourwing saltbush improved by scarification and grading. U.S. Dep. Agr., Forest Serv., California Forest and Range Exp. Sta. Res. Note 125,5 p.

Nord, E. C., D. R. Christensen, and A. P. Plummer. 1969. Atriplex species (or taxa) that spread by root sprouts, stem layers, and by seed. Ecology 50:324-326. 
Osborn, J., J. Letey, L. F. Debano, AND E. TERry. 1967. Seed germination and establishment as affected by non-wettable soils and wetting agents. Ecology 48:494-497.

Plummer, A. P., D. R. Christensen, AND S. B. Monsen. 1968. Restoring big-game range in Utah. Utah Division Fish and Game Publ. 68-3. $183 \mathrm{p}$.

Reynolds, H. G., F. Lavin, and H. W. SPRINGFIELD. 1949. Preliminary guide for reseeding in Arizona and New Mexico. U.S. Dep. Agr., Forest Serv., Southwest Forest and Range Exp. Sta. Res. Rep. 7, 14 p.

Russell, E. J. 1950. Soil conditions and plant growth. Longmans, Green \& Co., New York. 635 p.

Springfield, H. W. 1963. A seeding test with fourwing saltbush (Chamiza) in Western Ncw Mexico. U.S. Dep. Agr., Forest Serv., Rocky Mountain Forest and Range Exp. Sta. Res. Note RM-11, 11 p.

SPringfield, H. W. 1966. Germination of fourwing saltbush seeds at different levels of moisture stress. Agron. J. 58:149-150.

Springfifild, H. W., and D. G. Bell.. 1967. Depth to seed fourwing saltbush. J. Range Manage. 20:180-182. Springfield, H. W., and R. M. HousLEY, JR. 1952. Chamiza for re- seeding New Mexico Rangelands. U.S. Dep. Agr., Forest Serv., Southwestern Forest and Range Exp. Sta. Res. Note 122, 3 p.

Stroh, J. R., and A. A. Thornburg. 1969. Culture and mechanical harvest of fourwing saltbush under irrigation. J. Range Manage. 22:60-62.

U. S. Soll Conservation Service. 1967. Soil classification, a comprehensive system, 7th approximation. Supplement. March. 207 p.

Vosler, L. C. 1962. An ecological study of Atriplex nuttallii in the Big Horn Basin of Wyoming. M.S. thesis, Univ. of Wyoming, Laramie, Wyo. 38 p. 